\title{
How Racism Takes Place by George Lipsitz. Temple University Press, 2011. Pp. 320. \$26.95 (paper). ISBN: 978-1439902561
}

\section{Reviewer: Emma Gaalaas Mullaney ${ }^{1}$}

[Article copies available for a fee from The Transformative Studies Institute. E-mail address: journal@transformativestudies.org Website: http://www.transformativestudies.org (C2011 by The Transformative Studies Institute. All rights reserved.]

For his 1970 piece Injustice Case, African American artist David Hammons covered himself in margarine and pressed his body against a large sheet of paper. He sprinkled the resulting impression with black powder to reveal a human silhouette sitting bound and gagged, seemingly caged inside the American flag that serves as a frame, its stripes turned vertical like prison bars. As the grease on the paper evaporates over time, the image - a reference to the trial of Black Panther Bobby Seale in 1969 - fades as well, becoming even more poignant as it disappears.

In How Racism Takes Place, George Lipsitz turns to Hammons' art, and many other works of expressive culture emerging from twentieth century Black communities, as constituting "a living archive of oppositional consciousness and thought" capable of inspiring and guiding ongoing struggles for social change. This book and the political art so celebrated in its pages, in addition to sharing a common emancipatory cause, both have an immediate disruptive impact on their respective audiences. Through Hammons' image and Lipsitz's writing, we bear witness to the long, dark history of racial subjugation in the United States and, perhaps even more powerfully, to how seldom this

\footnotetext{
${ }^{1}$ Emma Gaalaas Mullaney is a PhD Candidate at The Pennsylvania State University, pursuing a dual-degree in Geography and Women's Studies. Her research interests include postcolonial studies, feminist political ecologies, and ethnographic methodologies. Her current work includes a study of post-9/11 policing of youth in Philadelphia, and her dissertation focuses on an environmental history of maize cultivation and agricultural development in central Mexico.
} 